\title{
THE ETERNAL YOUTH OF THE APOSTOLIC CANON 85 \\ (Youth without aging, and life without death)
}

Nicolae-Coriolan Dura*

Abstract: As mankind has arrived at the end of the 20th century and the beginning of the $21^{\text {st }}$ century, the European society in general, and especially the Romanian society have been offered the opportunity to make a survey. A survey regarding both the national and the European desiderata alike. The changes by which the civilian society challenged the citizen with it offers, temptations and anxieties managed to offer a way or an alternative to follow when choosing it and trying to fulfil it. The accomplishment of a unique Europe, with common rights and obligations represented a goal in which it has been invested a lot. Maybe nobody could tell at present how much time, how many destinies, funds and ideals have been invested in this desideratum. We speak about an offer of the 20th century which, unfortunately, has begun to shake in all its joints.

Keywords: young, canon, Orthodox Church, catechumen, baptisterium, ecumenical synod, local synod.

\section{Introduction}

Obviously, the title is quite inciting. Taken from a charming Romanian fairy tale conceived by the wisdom of our grandparents and dedicated to the wonderful age of childhood, it has its primary goal to pave the way for the forthcoming life of the youth.

Having to face such a challenge, the citizen, no matter the cultural level, age, nationality, sex and especially religion, was thrown into the mixing bowl of history. The tempest of new currents has helped man to face such challenges, as the new problems were not ready to accept old answers.

\footnotetext{
* PhD, Assistant Professor, Faculty of Orthodox Theology at "1 December 1918" University, Alba Iulia, Romania.
} 
Individuals, as well as fundamental institutions implied in building up the society and the nations, have been summoned up before such challenges. While elder people had the treasure of their experience and the efforts of their innermost soul, the young have been exposed directly and not seldom violently to the confrontation with the problems of their future. Too tender for confrontations, too unripe for such battles, immature to take decisions, they finished by being deprived of the elementary weapons they needed to defend themselves, in favour of the conclusions demanded to be taken by a majority of democratic votes. Bi-millenary values which had contributed to the formation of sound structures of the society were to be questioned and then destroyed.

With a hideous grin of history, the unjust roller of time was not satisfied by destroying them itself but, by manipulating the young, made them destroy them themselves.

The present study is meant to settle the present time of history by referring it to the historical past and, especially, to the eternity of the future. In other words: what are the answers the Orthodox church can offer as regarding the confrontations inside the society and, especially which are the answers offered to the young generation.

The Christian church and especial by the Orthodox Church offer the young generation the only treasure worth being taken into account. The age of man is ephemerical and his fate is that of an alien and stranger on earth (Hebr. 11:13). This fact is proven by both man's everyday life and the history of mankind alike.

\section{The old testamentary youth as testimony for the Christian church}

The old testamentary history constitutes, undeniably the vein, of the fact that man, since his youth, has got a structural unique, personal as well as pluralistic, communitarian character. The latter is to be developed early inside the family and then in society or 
community which society should be the extension, of the atmosphere in one's family.

The whole democratic system of the society and of the decision of the majority vote are ultimately based on the last mentioned fact.

How else could we explain the episode of offering of the first young men from the history of mankind, namely Cain and Abel. How could they understand the meaning of offering to Lord? How did they come to pray? From where did they know to whom or how to pray? All these numerous questions have just one answer: from their family, from their parents more precisely. The same biblical episode proves the fact that man, from early youth, can be formed on one single condition which has been taken into account both by God and by the Evil one, that is without any constraint on their choice, their free judgement.

The fact that the family has the first responsibility in forming the young can be demonstrated by the multiple examples from the biblical history and not only of mankind. Here are some eloquent examples. Joseph's brothers in Egypt, at Pharaoh's court sit at table according to a custom they were taught at home, namely according to age, which makes the assistance astonish (Gen. 43:33). Also they confess that they were taught to work honestly and in dignity in order to earn their daily bread, saying that they have tended livestock from their boyhood (Gen. 46:35).

Moses, who was raised in a sophisticated culture at the Pharaoh's court, is quite aware of the importance and responsibility of raising up the young and moulding their character. There are two important moments in his period. Formerly, the moment when he asks the Pharaoh's permission to let him bring offerings to the Lord taking with him not only the elderly, but especially the young (Ex. 10:8), and then the moment when he climbs the Sinai Mountain to get the New Stone Tablets. Those who are permitted to bring offering and sacrifices for the people's sins are the young (Ex. 24:5). Where from could Moses know that if not from his own mother? 
Who gets Samuel respect and admiration from the people and grace form God if not the fact that the boy continued to grow in stature and in favour with the Lord and with the men (I Kings 2:26).

May it have been just a chance that the tender youth of David was preferred to the maturity of Saul to be conferred the throne of the kingdom of Judah? Which must have been the reason for God's decision if not the noble innermost soul moulded inside the family. When David himself comes to old age he acknowledges the role of the family, especially that of the wife in how the young are raised up: Your wife will be a fruitful vine within your house your sons will be like olive shoots around your table. Thus is the man blessed who fears the Lord (Ps. 127:3-4.

Solomon tasting of the well of wisdom he bestows it as a gift on his son, on the generations to follow, more precisely: Listen, my son, to your father's instruction and do not forsake your mother's teaching. They will be a garland to grace your head and a chain to adorn your neck (Prov. 1:8-9).

No one can deny the fact that man's inclination of heart is evil from early childhood (Gen. 8:21), or that a young person comes to do evil if he is advised to. Samson makes a feast of seven days as it was customary from bridegrooms (Judges 14:10), and Job's sons used to take turns holding feasts in their homes (Job 1:4). The most conclusive example however, is that of the sons of the judge Samuel, as the unjust they commit will cause the rupture between theocracy and royalty. The episode can be found in the Holy Scriptures:

"When Samuel grew old, he appointed his sons as judges for Israel ... But his sons did not walk in his ways. They turned aside after dishonest gain and accepted bribes and perverted justice. So all the elders of Israel gathered together and came to Samuel at Ramah. They said to him, 'You are old, and your sons do not walk in your ways; now appoint a king to lead us, such as all the other nations have" (I Kings $8: 1-5)$. 


\section{The new testamentary youth as testimony for the Christian church}

The dominant characteristic of the family in training the young is obvious in the thorough new testamentary revelation. The presence of the Saviour Jesus Christ by the side of the Holy Virgin Mary and his father, old Joseph, at the temple plays a decisive part. Since he was eight days old to the age of thirty, more precisely when he began His public activity, He had been presented by the evangelists only together with His family when participating in major religious events: Every year His parents went for the Feast of the Passover to Jerusalem (Lk. 2:41).

Even though the only episode from our Saviour Jesus Christ's childhood mentioned by the evangelist Matthew was when He was 12 years old, we however know that our Saviour was always present at the temple of Jerusalem on the celebration of the Passover, which the Sanhedrin knew very well, too: What do you think? Isn't he coming to the Feast at all? (John 11:56).

Youth is an age decisive for man's future, and no one should neglect the privilege of admiring a pure young soul. Our Saviour himself acts like that when hearing the confession of the rich young man: All these I have kept since I was a boy (Matth. 19.20; Mk. 10:20; Lk. 16:9; 18:21), which makes Jesus look at him and love him (Mk. 10:21). At the same time, the human society acknowledges that at all important events in our Saviour Jesus Christ's life, when he was surrounded by a large crowd of people, those belonging to an early age childhood or youth were present there beside their parents.

Who could question the fact that on multiplying the five loaves of bread and two fish: The number of those who ate was about five thousand men, besides women and children (Matth. 14:21), or should anyone not admit that by the Sea of Galilee up on a mountainside, after multiplying seven loaves of bread and a few little fish, the men ate and were satisfied: the number of those who ate were about four thousand men, besides women and children (Matth. 
15:38), thus proving the presence of children beside their parents as well as the parents' care about their children.

So we should not be surprised at the children's presence around our Saviour, fact very well proven, as

\begin{abstract}
"people were bringing children to Jesus to have him touch them, but the disciples rebuked them. When Jesus saw this, he was indignant. He said to them, 'Let the little children come to me, and do not hinder them, from the kingdom of God belongs to such as these ... And he took the children in his arms, put his hands on them and blessed them" (Mk. 10:13-16; Matth. 19:13-15; Lk. 18:15).
\end{abstract}

All the above being said, who would wonder about the children's presence in Jerusalem, at the temple on the occasion of the feast of the Passover, when on our Saviour Jesus Christ's entrance into Jerusalem they play a special part. Their attitude is not only registered, but it has consequences, arising disputes (Matth. 21:15; Mk. 11:18).

Could it be just by change that out of the three miracles of resurrection from the dead, two were addressed to young people. At first it was a 12-year old girl for whose bringing up her parents were responsible, her father's name was well-known as well as his position in society (Lk. 8:41). Then the young man from Nain whose widowed mother without any other children utters her grief in a most eloquent manner (Lk. 7:11-15). The words: Young man, I say to you get up! (Lk. 7:14), or: My child, get up! (Lk. 8:54) are also listened to by another young man who our Saviour Jesus Christ summoned up to the apostolic dignity and who will be also called the disciple whom Jesus loved. We are talking about Holy Apostle John mentioned at the Last Supper (John 21:20), as well as in Gethsemane.

The fact that the youth may be mischievously influenced and that innocence may be easily lost is also admitted by our Saviour Jesus Christ when he says: 
"Woe to you, teachers of the law and Pharisees, you hypocrites! You shut the kingdom of heaven in men's faces. You yourselves do not enter, nor will you let those enter who are trying to [...] You travel over land and see to win a single convert and when he becomes one, you make him twice as much a son of hell as you are" (Matth. 23: 13-15),

thus the atmosphere in the society is perverted, and the meaning of youth and of the young is being mutilated and the moment will come when brother will betray brother to death, and a father his child; children will rebel against their parents and have them put to death (Matth. 10:21). We should then wonder at the expression: Let his blood be on us and on our children! (Matth. 27:25).

No one knows better this painful aspect of how young conscience could be manipulated but Saul, native of Tars from Cilicia, who was raised with the lie that has been widely circulated among the Jews to this very day that Jesus from Nazareth had not resurrected but that his disciples came during the night and stole him away while we [the soldiers] were sleep (Matth. 28:13-15). Saul is the one who put his youth at the disposal of lie without even suspecting that his trust could be manipulated. This is how we should understand his presence at and approval to the death of Archdeacon Stephan (Acts 7: 58), as well the persecution he set off against the Church in Jerusalem. Saul of Tars confesses his youth and manipulation before king Agrippa and the persecutor Porcius Festus (Acts 25:4-5), as well as to the Christian communities from Galatia: I was advancing in Judaism beyond many Jews of my own age and was extremely zealous for the traditions of my fathers (Gal: 1:14).

For all these he is entitled to give advice. Due to his apostolic love shown by Holy Apostle Paul to the young he came to know in the communities he had founded while getting to know the families these young people belonged to, he considered to offer some of them the difficult mission of priests or bishop. Thus Timothy is advised to take great care of his youth (II Tim. 2:11) so that it should be a reason of admiration and respect and not of contempt: Don't let 
anyone look down on you because you're young (I Tim. 4:12). Becoming a source of respect, young Timothy has the right to advise others too:

"Do not rebuke an older man harshly, but exhort him if he were your father. Treat younger men as brothers, older women as mothers, and younger women as sisters, with absolute purity ... But a widow has children and grandchildren, these should learn first of all to care for their own family and so repaying their parents" (I Tim. 5:1-4).

\section{Which is in fact the role of the young in the Church? Can they be found in the new formed communities?}

The primary Christian church never considered it necessary to write about what seemed to be natural, just as we cannot speak about children without taking into account the fact that they have parents, and we cannot confer the title of parents but to people who gave birth to children.

The episode of the Crispus's conversation, the synagogue ruler's in Corinth (Acts 18:8), as well as that of the centurion Cornelius (Acts 10:24) point out the presence of children in the church since early age already. The presence of the young in the church since early age in the middle of the Christian community is pointed by Holy Evangelist Luke in two locations, in Jerusalem and Troa.

In Jerusalem, in the early days of the foundation of the Church when Ananias, slyly converted, dies after talking to Holy apostle Peter. After his death the young men came forward, wrapped up his body, and carried him and buried him (Acts 5:6). The young people come to the community, being permanently present by the side of the Apostles, as Holy Apostle Peter tells Anania's wife Saphira the following: Look! The feet of the men who buried your husband are at the door, and they will carry you out also. At that moment she fell down at his feet and died. Then the young men came 
in and, finding her dead, carried her out and buried her beside her husband. (Acts 5:9-10)

In Troa, another Apostle, Holy Apostle Paul this time, is implied in such an episode, and a young man is now the beneficiary of a miracle. The Christian community from that place has been witness over centuries:

„There were many lamps in the upstairs room where we were meeting. Seated in a window was a young man named Euthychus, who was sinking into a deep sleep as Paul talked on and on. When he was sound asleep, he fell to the ground from the third story and was picked up dead. Paul went down, threw himself on the young man and put his arms around him. 'Don't be alarmed' he said. He's alive! Then he went upstairs again and broke bread and ate. After talking until daylight he left. The people took the young man home alive and were greatly comforted" (Acts 20:7-12).

Especially edifying is the case of a young assistant of Holy Apostle Paul. It is about Timothy, who was very close to the Apostle, whom the latter meets in Lystra during his second missionary journey, in his parents' house who were about to convert themselves as Christian His mother was of Judaic confession and his father was a Greak. Holy Apostle Paul took the young man in his missionary journeys and not rarely entrusted him tasks he had to accomplish far away from the Apostle. Afterwards he entrusted him the mission to preach among the Jews, finally being conferred the post of bishop of Ephesus (Acts 16:1-3).

\section{The Church in Jerusalem, a canonical apostolic model}

The commission ${ }^{1}$ given to the Apostles by our Saviour Jesus Christ was put into practice immediately after the investment with

${ }^{1}$ Therefore go and make disciples of all nation, baptizing them in the name of the Father and the Son and of the Holy Ghost, and teaching them to obey everything I have commanded to you (Matth. 28: 19-20). 
the power of the Holy Ghost at the Pentacost. The preaching of Holy Apostle Peter had a great effect, as those who accepted his message were baptized, and about three thousand were added to the number that day (Acts 2:41; 5:14). While they were teaching the people the Word of God, the Sanhedrin were greatly disturbed by the straightforward attitude of Holy Apostle Peter. While the first confrontation has as a result the disturbance of the Sanhedrin (Acts 4:1-14), what the Apostle replies further on, will set forth the course which the church will follow firmly: Judge for yourselves whether it is right in God's sight to obey you rather than God. For we cannot help speaking about what we have seen and heard (Acts 4:19-20). Even though the second confrontation is violent, as the Apostle are beaten and imprisoned, their attitude stays the same (Acts 5:29-32). We can also see that those three journeys of Holy Apostle Paul were meant to change the face of an empire.

While Christianity was becoming a new way of life and it was embraced by more and more people, the mission of the Apostles became more and more difficult. Perfectly aware of These aspect and of the fact that their mission as Apostles is not to settle down in one place or another, the Holy Apostles ordain bishops, priests and deacons to scatter the seed (Luke 8:5) to yield good crop.

Thus it is registered the activity and mission of the first seven deacons, out of which the example of Holy Archdeacon Stephen is convincing for eternity (Acts 7:2-53). Chapter 11 from the Acts registers the fact that in Judea priests were appointed, who were to gather gifts to help their communities by Barnabas and Saul (Acts 11:29-30). The priests were also confronted to new missionary issues while trying to put into practice their mission and they demanded an answer valid to the entire Christian church. The solution to the above mentioned thing was the summons of the Apostolic Synod in Jerusalem (Acts 15:2; 15:6; 15:22). Paul will meet the same priests' before the journey of his captivity (Acts 21:18-26). Such priests were ordained not only in Jerusalem, but also in Derbe, Lystra, Iconium and Antioch (Acts 14:20-21), Paul and Barnabas appointed 'priest' 
in each church (Acts 14:23). As well as in Miletus, Holy Apostle Paul and Barnaba sent to Ephesus for the priests to bid farewell (Acts 20:17).

The Christian teaching after being preached has come to be known not only by Christians, but also by Pagans. At first just curiosity, it became a special subject to be interested in. It the case of the prosecutor Felix from Caesarea to whom the teaching came before Holy Apostle Paul, as he was well acquainted with the Christian way, he adjourned the proceedings (Acts 24;22). He also wanted his wife Drusilla, who was a Jewess, to get acquainted with the new teaching (Acts 24;24).

The testimony for the time spent by the Church during the period of Judaic and Roman persecutions is characterized by discretion regarding the unrest of those times. From time to time we are offered newly discovered martyrs and archeology reveals fragments from a religious life both charming, and tumultuous. But the atmosphere of those times remained written down in the decision taken by synods, which have preserved the apostolic tradition; a tradition which sometimes is difficult for the modern man to understand.

How could we nowadays understand the content of some apostolic canons which stipulate the obligatory character of teaching the true faith to the believers ${ }^{2}$ from the point of view of the sacramental hierarchy on one side and, on the other side the duty of the believer to participate in the Liturgy of the Word and the Eucharistic Liturgy every Sunday, not only receiving the Body and the Blood of our Saviour, but also the Word of $\mathrm{God}^{3}$. In secularized

${ }^{2}$ Apostolic canon no. 58: "The bishop and the priest who does not care about
the clerics or the people who does not teach them the right honouring of God
shall be laid under the ban of the Church and if he will persist to do so and get
idle shall be defrocked", in: Constantin Dron, Canoanele, text şi interpretare,
vol. I, Bucharest, Cărţilor Bisericeşti Publishing House, 1932, p. 185-187.
${ }^{3}$ Apostolic canon no. 9: "All belivers who will enter and listen to the Scriptures
but who will not stay to pray and receive the Eucharist shall be anathemized as 
world, where the immediate present decides, upon the fate of the present it becomes very difficult for a young person to halt, from the rush of history so that he may not become just a leaf at the disposal of the stormy winds of time, but become the strong root of a glorious oak tree being able to write down his own destiny in the history.

At present, in most cases, the young are baptized since early age. While growing up physically, a spiritual birth takes place. Christianity means for them a gift from the part of their families and the Church, also implying a great responsability for themselves their godfathers and for the Church as well. Why this responsibility?

Firstly, in the primary period of Christianity it did not represent a gift, something that you could obtain by yourself, but it represented the climax of an effort made along several years, the climax of freely ascending a spiritual slope passionately worked upon. And thus a natural question comes forth: How else could you become a Christian if not like today?

First of all, in order to yearn after this, you should have listened to the preached word of the Gospel, here from the obligatory character for both the sacramental hierarchy (bishops, priests, deacons) to preach or to teach the people, and for the people to master this Word and to spread it by deed, making it alive.

Secondly you had to express your wish to became a Christian, to be the same as those you admired a lot. Your wish had to be told to a Christian (laic or cleric) who became the warrant for your sincere wish, as he was the one to take you to a priest or a bishop. The latters had to make sure that your wish was sincere, after which, by making a prayer for introducing him into the range of the catechumens, he made a cross on the catechumenen. After getting into the body of Church you were entrusted to a deacon, and in the period when the catechists were a special category of the Church or

they cause disorder in The Church", in: Nicodim Milaş, Canoanele Bisericii Ortodoxe, insoţite de comentarii, translated by Uroş Kovincici and Nicolae Popovici, vol. I, 1-st Part, Arad, Diecezană Publishing House, 1930, p. 204206. 
in the period when exorcists existed ${ }^{4}$, to one of them, who were responsible for your formation as regarding the main notions of Christianity. For their effort they could by paid (Gal. 6:6).

The period of catechumenate consisted of several stages. The canonist Nicodim Milaş is in favour of two, considering them the most important: a) those who have just entered and b) others who have developed ${ }^{5}$.

In what a wonderful world a catechumen could have felt while, over the week, he was accepted in the buildings especially laid out for the catechumens ${ }^{6}$, in a court rustling with people (Christians and future Christians), where the deaconesses were responsible for catechizing the women ${ }^{7}$, and the deacons for catechizing the men, and on, Sundays he was allowed to enter the church.

${ }^{4}$ Canon no. 26, of the V-th local synod, in Laodiceea, in: Ibidem, vol. II, 1-st Part, Arad, Diecezană Publishing House, 1934, p. 89-90.

5 Nicodim Milaş, Canoanele Bisericii Ortodoxe, insoţite de comentarii, translated by Uroş Kovincici and Nicolae Popovici, vol. I, 2-nd Part, Arad, Diecezană Publishing House, 1931, p. 66.

${ }^{6}$ Canon no. 97 of the V-VI-th Eumenical Synods, in Constantinople, in: Ioan N. Floca, Canoanele Bisericii Ortodoxe, note şi comentarii, Sibiu, 2005, p. 175-176.

${ }^{7}$ Canon no. 15 of the IV-the Ecumenical Synod, in Chalcedon: " $A$ woman shall not receive the laying on of the hands as a deaconess under forty years of age, and they only after searching examination. And if, after she has hands laid on her and has continued for a time to minister, she shall despise the grace of God and give herself in marriage, she shall be anathemathized and the man united to her too", in: Nicodim Milaş, Canoanele Bisericii Ortodoxe, insoţite de comentarii, translated by Uroş Kovincici and Nicolae Popovici, vol. I, 2-nd Part, Arad, Diecezană Publishing House, 1931, p. 228. When the baptizing of the little children will take root this rank shall no more exist, in Nicodim Milaş Canon no. 11 of the V-th local synod, in Laodiceea: "Presbyteres, as they are called, or female presidents are not to be appointed in the church", in: Nicodim Milaş, Canoanele Bisericii Ortodoxe, insoțite de coomentarii, translated by Uroş Kovincici and Nicolae Popovici, vol. II, 1-st Part, Arad, Diecezană Publishing House, 1934, p. 89-90. 
The assimilation of the main knowledge was according to a weekly schedule of five days, which was well-established. It started on the first day of the week (on Sunday) and ended on the fifth day of the week (on Thursday), when the catechumens had to come before the priest or the bishop to show the knowledge they had acquired $^{8}$.

The assimilation of general knowledge began on the first day (on Sunday) at the Holy Liturgy. It was then when he or she was firstly allowed to step into the church of Christ. He left behind the church porch where the wailers were staying, the most severe category of penitence for the Christians, those who were bewailing their sins while asking those entering to church to pray for them ${ }^{9}$.

Then he entered the hall of the church. There he could enjoy a whole universe developing before his eyes standing on the right side of the font or baptisterium, beside other catechumens, some of them on the second stage of the catechumenate, all of them very much preoccupied by going deeply into the study of the Faith and by the elements of the Niceo-Constantinopolitan faith symbols. The second category, were allowed to kneel and bend their heads when the priest or bishop was reading prayers upon them ${ }^{10}$. He was

${ }^{8}$ Canon no. 78 of the V-VI-th Ecumenical Synod, in Constantinople: "Those who are to be enlightened must learn the faith creed by heart and recite it to the bishop or, to the presbyters on the fifth day of the week", in: Constantin Dron, op. cit., p. 347, as well as Canon no. 46 of the V-th local synod, in Laodiceea: "Those who want to be enlightened should learn the creed and recite it to the bishop or to the presbyters on the fifth day of each week", in: Nicodim Milaş, Canoanele Bisericii Ortodoxe, insoţite de coomentarii, translated by Uroş Kovincici and Nicolae Popovici, vol. II, 1-st Part, Arad, Diecezană Publishing House, 1934, p. 113.

9 Nicodim Milaş, Canoanele Bisericii Ortodoxe, insoţite de coomentarii, translated by Uroş Kovincici and Nicolae Popovici, vol. I, 2-nd Part, Arad, Diecezană Publishing House, 1931, p. 56.

${ }^{10}$ Canon no. 19 of the V-th local synod, in Laodiceea, in: Andrei, baron de Şaguna, Enchiridion adeca Carte manual de canone ale unei, sântei, sobornicesci, si apostolesci Biserici cu comentare, Sibiu, Arhidiecezană 
watching the baptisterium and listening to the words of our Saviour Jesus Christ told to Nicodemus: I tell you the truth no one can see the kingdom of God unless he is born of water and the Ghost (John 3:3). He was allowed to listen, through the open doors of the church, to the Holy Scripture and the preaching of the word which followed immediately after the Holly Gospel had been read. To attend the litanies and prayers till the words: Those called exit .... To long for the communion with Eucharistic Christ after the doors had been closed, and the last words they heard were: The doors, the doors! In wisdom let us attend. What an intense moment might the catechumen have lived when the deacon (catechist or exorcist) presented him to the bishop announcing that the period of the catechumenate had been finished and this expectation came to an end the last day of the 'casum ligat' (of the câşlegi period), a day before Christians entered the Lent Period. On this occasion he received from the bishop a new name of a Christian which was registered among those called for the holy enlightment. From now on, from the first day of the Lent, he was permanently present at the Holy Liturgy, praying and fasting beside the Christians, that is he put into practice everything he had learnt during his period of catechumenate, preparing himself for the glorious day of the Lord's Resurrection when he could express his firm will to give up his stained life, lived in sin as well as his wish to unite with Jesus Christ while declaring his Symbol of Faith (the Creed) three times, as a synthesis of what he believes and will confess till the end of his life (an end which was not always to be expected to be mild, but violent and cruel).

What were they being taught or, more precisely, where did they take this teaching of faith from at a time when Christianity was at its debut in history?

We are offered an answer by the concerns of the local ecumenical synods and the canons (decisions) of the Holy Fathers.

Publishing House, 1871, p. 256-257. See also Liturghier, Bucharest, The Biblical and Missionary Institute of the Romanian Orthodox Church Publishing House, 2000, p. 143, 145, 147. 
Thus, the VI-th Ecumenical Synod, held in Constantinople in 692, in canon $2^{11}$ does nothing else but to mention a state of facts and to legitimate it, what had already existed in the practice of the Church. The Holy Fathers took attitude at the local synods as this phenomenon was regarded; while the apostolic canon 85 disposed the obligativity of preaching the word of the Gospel, the local synod held at Laodiceea, in 349, through its Canons 59 and 60 decided the contents of the books of the Holy Scriptures. And at the local synod held in Carthagene, held 70 years after, the Holy Fathers legitimate this very aspect in Canon 24. In the same historical context, three of the Holy Fathers especially mentioned the well of the godly revelation, in the context of the emerging apocryphal writings. We speak about Holy Athanasius the Great (†373) who, in Canon 2 in the range of the canons, enumerates the books inspired and good for reading, as well as about Holy Gregory the Theologian $(\dagger 389)$ and the Holy Amphilohius ( $\uparrow 395)$, the ones who only left one Canon.

How could a young man of our times feel the thrill of uttering from 5.000 chests the Symbol of Creed on the Holy day of Easter or of approaching, for the first time to the chalice with the Holy Body and the Holy Blood of our Saviour Jesus Christ, the outcome of five-years waiting and spiritual unrest. But for the catechumen this meant nothing but the beginning of his new life.

\section{Conclusions}

Our old books ${ }^{12}$ speak about such a world, but the books remain in some dusty corners of a library. The words of the Holy Fathers with an abundant well of eternal life remain buried under the ashes of time. The roller of history has gone over the whole world

11 Alexandru I. Stan, Sfintele canoane ale Bisericii Ortodoxe a Răsăritului, Bucharest, Nicora M Publishing House, 2016, p. 157.

12 See Pidalionul sau cârma Bisericii, Bucharest, „Credinţa strămoşească” Publishing House, 2013; Indreptarea Legii, 1652, Bucharest, The Romanian Popular Republic Academy Publishing House, 1962. 
and over the Romanian people. The tempest of communism has mutilated destinies and destroyed hopes. Sound generations of the Romanian people have been pulled out of their roots. Dignified sacramental ministers (bishops, priests and deacons), truly spiritual fathers, were brutally raped from their flock, from their sons. Biological parents with pure souls were estranged, in the middle of the night, from their own children. They who were to from and protect the new generation of Romanians and of Christians, they who represented the root of the Romanian people were uprooted from the off-springs who had to be engrafted on foreign roots. Painful wounds which cannot scar over, roots that cannot heal anymore, unfruitful off-springs.

The young generations nowadays, who were raised up far from Christ forgot the way of the catechumens and some of them do not know there is such a way. They wonder how was it possible, in a period without internet, mobile phone or satellite connection, for some people to write homilies to be admired nowadays without any danger of becoming anachronical. Where could such people be brought up, young people who managed to change the history of the world?

There is just one answer: as young people at the catechetic schools of their time, where their parents had entrusted them to the Church.

\section{References}

1. *** Biblia sau Sfânta Scriptură, jubilee Edition of the Holy Synod, printed with the blessing and Foreword of His Beatitude Teoctist, The Patriarch of Romanian Orthodox Church, Bucharest, The Biblical and Missionary Institute of the Romanian Orthodox Church Publishing House, 2001.

2. *** Indreptarea Legii, 1652, Bucharest, The Romanian Popular Republic Academy Publishing House, 1962.

3. *** Liturghier, Bucharest, The Biblical and Missionary Institute of the Romanian Orthodox Church Publishing House, 2000. 
4. *** Pidalionul sau cârma Bisericii, Bucharest, „Credinţa strămoşească Publishing House, 2013.

5. Andrei, baron de Şaguna, Enchiridion adeca Carte manual de canone ale unei, sântei, sobornicesci, si apostolesci Biserici cu comentare, Sibiu, Arhidiecezană Publishing House, 1871.

6. Dron, Constantin, Canoanele, text şi interpretare, vol. I, Bucharest, Cărţilor Bisericeşti Publishing House, 1932.

7. Floca, Ioan N., Canoanele Bisericii Ortodoxe, note şi comentarii, Sibiu, 2005.

8. Milaş, Nicodim, Canoanele Bisericii Ortodoxe, insoţite de comentarii, translated by Uroş Kovincici and Nicolae Popovici, vol. I, 1-st and 2-nd Parts, Arad, Diecezană Publishing House, 1930, 1931.

9. Milaş, Nicodim, Canoanele Bisericii Ortodoxe, insoţite de comentarii, translated by Uroş Kovincici and Nicolae Popovici, vol. II, 1-st Part, Arad, Diecezană Publishing House, 1934.

10. Stan, Alexandru I., Sfintele canoane ale Bisericii Ortodoxe a Răsăritului, Bucureşti, Nicora M Publishing House, 2016. 